\title{
PENINGKATAN KEMAMPUAN MENULIS PERMULAAN DENGAN METODE ANALISIS GLASS
}

\author{
Khusna Yulinda Udhiyanasari ${ }^{1}$, Nostalgianti Citra Prystiananta ${ }^{2}$ \\ IKIP PGRI JEMBER ${ }^{1,2}$ \\ Khusnayulinda37@gmail.com ${ }^{1}$
}

\begin{abstract}
ABSTRAK
Penelitian ini bertujuan untuk mengetahui peningkatan kemampuan menulis permulaan dengan menggunakan metode analisis glass. Penelitian ini merupakan studi kasus terhadap anak kelas 1 sekolah dasar yang mengalami kesulitan menulis permulaan. Setelah dilakukan identifikasi faktor utama anak mengalami kesulitan menulis (disgrafia) yaitu faktor dalam diri anak sendiri dan lingkungan terutama orang tua dan kebiasaan sehari-hari dirumah. Penggunaan metode yang kreatif seperti metode analisis glass yaitu pemisahaan suku kata persuku kata akan mempermudah siswa dalam menulis karena mengingat satu persatu suku kata yang akan dirangkai menjadi sebuah kata dan kalimat. Simpulan, pemberian pembelajaran dengan menggunakan metode analisis glass dapat memberikan peningkatan dalam kemampuan menulis permulaan siswa
\end{abstract}

Kata Kunci: Kemampuan Menulis, Metode Analisis Glass

\begin{abstract}
This study aims to determine the increase in the ability to write early using the glass analysis method. This research is a case study of grade 1 elementary school students who have difficulty writing beginning. After identification of the main factors children have difficulty writing (disgrafia), namely factors in their own children and the environment, especially parents and daily habits at home. The use of creative methods such as the glass analysis method, namely the separation of syllables, makes it easier for students to write because they remember one by one syllables that will be arranged into a word and sentence. Conclusion, the provision of learning using the glass analysis method can provide an improvement in the writing ability of students' beginning
\end{abstract}

Keywords: Writing Ability, Glass Analysis Method

\section{PENDAHULUAN}

Hal yang paling esensial bagi peradapan sebuah bangsa adalah Pendidikan yang berkualitas. Karena dengan keberhasilan pendidikan yang berkualitaslah seseorang akan mampu keluar dari jerat kemiskinan, kemiskinan yang dimaksud adalah kemiskinan dalam aspek koqnitif, sosial maupun finansial.

Keberhasilan pendidikan,terbukti juga mampu mengangkat derajat seseorang ke strata sosial yang lebih tinggi dari sebelumnya, maka dari itu jika 
setiap orang telah berhasil dalam pendidikan yang berkualitas maka akan berdampak positif pada setiap individu di masyarakat, lembaga pendidikan dan bahkan sebuah Negara (Saebani, 2007)

Untuk memperoleh pendidikan yang berkualitas maka, sebuah lembaga sekolah, seluruh staf, kepala sekolah maupun pemangku jabatan tertinggi dalam lembaga pendidikan tersebut memiliki kemampuan untuk mengembangkan kualitas pendidikan yang dimulai dari para guru yang memiliki semangat untuk mengembangkan semua potensi yang dimiliki oleh setiap peserta didik.

Parameter dari keberhasilan sebuah pendidikan adalah terjadi sebuah proses perubahan yang signifikan, dari keberhasilan sebuah proses pendidikan dan interaksi dengan lingkungan dalam komunitas pendidikan sehingga terjadi perubahan yang lebih baik . dalam bentuk pengetahuan, keterampilan dan sikap.

Ada empat keterampilan yang harus dimiliki oleh peserta didik untuk menguasai keterampilan berbahasa atau language skill (Walgito, 1980). Yang pertama adalah keterampilan membaca (reading skill). Jika peserta didik memiliki kemampuan membaca dengan baik maka mereka akan memiliki keterampilan berbicara (speaking skill), selanjutnya peserta didik akan memiliki kemampuan menulis (writing skill) jika telah memiliki kemampuan membaca dan berbicara. keempat aspek tersebut diatas, saling terkait dan tidak dapat dipisahkan.

Kemampuan menulis peserta didik perlu dilatihkan secara bertahap sesuai dengan usia dan kemampuan akademik yang dimiliki terutama kematangan dalam perkembangan gerak motorik halusnya. Tahapan menulis awal harus dikuasai peserta didik terlebih dahulu, baru kemudian tahapan selanjutnya dilatihkan secara bertahap dan berkelanjutan.

Keterampilan menulis merupakan keterampilan yang paling kompleks dibanding keterampilan lainya (Abdurrahman, 1995). Karena dalam menulis inilah peserta didik dituntut menyampaikan ide, gagasan, maupun pikiran melalui bahasa tulisan. Dan hal ini bukanlah hal yang mudah bagi peserta didik yang mengalami hambatan dalam menulis (Yusuf, 2003)

Dalam Peraturan Menteri Pendidikan Nasional Nomer 23 Tahun 2006 tentang Standar Kompetensi Lulusan menyebutkan bahwa kompetensi yang diharapkan dari pembelajaran pada aspek menulis bagi peserta didik di Sekolah Dasar adalah peserta didik memiliki kemampuan untuk mengungkapkan apa yang dipikir, dirasa dan dilihat kemudian dituliskan dalam bentuk tulisan yang bertujuan untuk memberikan informasidalam bentuk karangan yang sederhana, teks pidato, pengumuman, teks pidato, puisi, pantun maupun katrangan berupa cerita pendek. (Depdiknas, 2008)

Tujuan menulis disini tidak hanya menyalin namun yang terpenting adalah meningkatkan kemampuan untuk mengekspresikan pikiran dan perasaan dalam 
lambing-lambang tulisan. Sehingga peserta didik memiliki kemampuan dalam menyalin, mencatat dan mengerjakan tugas-tugas dari bapak dan ibu guru.

Dari berbagai alasan yang telah dikemukakan maka diambil kesimpulan bahwa menulis merupakan salah satu komponen sistem komunikasi dalam menggambarkan pikiran, perasaan, dan ide kedalam bentuk lambing-lambang grafis untuk kepentingan mencatat dan berkomunikasi dalaminteraksi sosial terutama di lingkungan pendidikan.

\section{METODE PENELITIAN}

Penelitian ini menggunakan metode penelitian studi kasus yaitu dalam penelitian ini peneliti memusatkan pada suatu kasus yaitu bagaimana cara meningkatkan kemampuan menulis permulaan pada siswa SD kelas 1. Dalam penelitian ini peneliti mengambil salah satu subyek penelitian yang memiliki nilai rendah dikelas dalam pelajaran bahasa Indonesia. Kemudian penelitian ini digabung dengan study pustaka yang merupakan sebuah gagasan yang telah peneliti lakukan sebelumnya.

Penelitian studi kasus memiliki tujuan untuk memberikan sebuah gambaran yang mendalam dan mendetail tentang sebuah permasalahan. Dalam hal ini yaitu memberikan gambaran kepada guru tentang kesulitan menulis permulaan dan metode yang tepat dalam memberikan pembelajaran kepada siswa yang memiliki kesulitan menulis sehingga akan memperbaiki nilai akademik siswa. Serta akan menjadi pedoman pembelajaran yang baik bagi orangtua siswa dirumah. Pembelajaran yang berkesinambungan antara sekolah dan rumah dimana guru dan orangtua memberikan suatu perlakukan yang sama.

\section{HASIL PENELITIAN}

Dalam penelitian ini peneliti mengambil salah satu subyek yaitu berinisial AS. AS merupakan siswa kelas 1 dengan jenis kelamin laki-laki, berusia 7tahun. Siswa AS memiliki nilai akademik yang kurang baik atau dibawah rat-rata. Hal ini dibuktikan dengan AS yang selalu mendapatkan nilai merah dikelasnya. Dengan data-data tersebut peneliti melakukan tindakan assessment yang bisa menyatakan bahwa AS mengalami kesulitan menulis. Salah satunya yaitu tidak bisa membedakan mana huruf b,d atau e,c atau v,u. selain itu ketika peneliti memberikan tugas untuk mendikte maka siswa AS bisa mengucapkan dengan benar tetapi dalam hal menuangkannya kedalam sebuah tulisan siswa AS mengalami kesulitan.

\section{PEMBAHASAN}

Setiap anak memiliki tingkat kesulitan yang berbeda-beda dalam setiap proses pembelajaran. Olehkarena dibutuhkan dukungan dari berbagai macam 
aspek, termasuk peran orangtua dan guru, lingkungan dalam proses pembalajaran, metode pembelajaran yang mendukung proses belajar anak sehingga dapat meningkatkan kemampuan akademik.

Peningkatan kemampuan menulis permulaan dibutuhkan karena dalam setiap proses pembelajaran selalu membutuhkan kegiatan menulis. Menulis merupakan salah satu cara dalam menyampaikan sebuah pesan. Dengan menulis akan memberitahukan banyak hal. Sehingga jika seorang siswa mengalami masalah dalam aktifitas menulisnya maka siswa tersebut akan mengalami penurunan nilai-nilai akademiknya.

Dari hasil assessment yang telah peneliti lakukan, maka peneliti mencari metode yang tepat yang dapat memberikan solusi dalam permasalahan AS. Metode analisis glass dipilih oleh peneliti karena metode analisis glass memiliki konsep pemecahan sandi dalam suku kata atau pemecahan suku kata per suku kata yang memudahkan siswa dalam mengingat huruf satu persatu dan merangkainya menjadi suatu kata dan akhirnya menjadi suatu kalimat.

Treatmen pembelajaraan menulis permulaan dengan menggunakan metode analisis glass beberapa kali dilakukan yaitu 3x dalam proses pembelajaran, terutama memahamkam konsep huruf yang tepat lalu menyatukannya dengan huruf lain sehingga menjadi suku kata yang terpisah-pisah. Peneliti melihat adanya perkembangan yang signifikan dari proses pembelajaran siswa AS setelah diberikannya treatmen dengan menggunakan metode analisis glass. Berdasarkan nilai dari hasil soal yang diberikan kepada AS setelah treatmen mengalami peningkatan dari sebelum diberikan treatmen pembelajaran menggunakan metode analisis glass.

\section{SIMPULAN}

Dalam penelitian ini, peneliti menyimpulkan bahwa pemberian pembelajaran dengan menggunakan metode analisis glass dapat memberikan peningkatan dalam kemampuan menulis permulaan siswa SD kelas 1.

\section{DAFTAR PUSTAKA}

Beni, A.,S. (2007). Metode Penelitian. Bandung: Pustaka Setia

Bimo, W. (1980). Bimbingan Penyuluhan. Yogyakarta: Yayasan Penerbit Psikologi UGM

Depdiknas. (2008). Sistem Baille Indonesia Bidang Bahasa Indonesia. Jakarta: Depdiknas

Mulyono, A. (1995). Pendidikan bagi Anak Berkesulitan Belajar. Jakarta: IKIP Jakarta Press

Munawir, Y. (2003). Pendidikan Bagi Anak dengan Problema Belajar. Solo: Tiga Serangkai 